特集 バイオテクノロジーと水処理技術

\title{
バイオテクノロジーを活用した都市下水処理・再利用技術
}

\section{Municipal Wastewater Treatment and Discharged water Reuse Using Bistechnology}

\author{
松 井大 悟*
}

わが国では, 1922年, 標準散水 3 床による本格的な 下水の二次処理施設が東京に建設された。1930年には 名古屋市に標準活性污泥プロセスが導入され，それ以 来, 活性污泥プロセスは下水処理の主流をなしている. 活性污泥プロセスは, 良好な処理水を得るために比較 的高度な技術と注意深い活性污泥のコントロールを必 要とするが, 二次処理プロセスとしては他のどの方法 よりも良質な処理水を作り出すという利点がある.

しかしながら, 水処理が良好に出来る反面, 大量に 発生する余剩污泥の処分のため広大な土地や，あるい は大きなエネルギーを必要とする.さらに処分地の確 保という行政上の課題を背負い続けなければならない。 特に大都市圏においては処分地の確保が相当困難にな ってきており，污泥の有効利用と並んで咸量化対策が 急務となっている. また，今後下水道の普及を推進し ていかなけ机ならない中小都市に打いては維持管理 の人手を確保するてとが難しい事情から運転管理が簡 単な処理方法が希求されている。 てのような理由から 活性污泥プロセスの改善を望む声は強い。さらに湖や 海の富栄養化防止に対して, 下水道が積極的な役割を 果たすべきだという観点から，富栄養化の原因となる 窒素やリンの除去率を安定的に高める技術の開発も望 まれている，乙の他にあ流入下水中に微量な有害物質 が含まれる場合にそれを分解・安定化する技術，処理 水再利用の際に望まれる処理水の脱色技術, そしてエ ネルギー資源に乏しいわが国の恒久的なニーズとして 省エネルギー型の下水処理技術など, 社会の複雑化と ともに下水道に要求される技術む多種多様となってき ている. 活性污泥技術が発見されて既に70年以上経っ ており，21世紀に向けて次世代の下水処理技術の礎を 築くべく，建設省では昭和 60 年度を初年度として 5 ケ 年計画で建設省総合技術開発プロジェクト「バイオテ クノロジーを活用した新排水処理システムの開発」を

\footnotetext{
*建設省都市局下水道部下水道企画課

Taigo MATSUI
}

建設省土木研究所下水道部, 建築研究所と日本下水道 事業団技術開発部を中心としてスタートさせた。

本プロジェクトは「バイオフォーカス WT」と呼ば れているが，本論ではてのプロジェクトが発足する背 景となったわが国の下水道事業の現状と下水処理技術 の課題，及びバイオフォーカス WT の概要と現時点で の進行状況について述べるととにする.

\section{1. わが国の下水道事業の現況と下水処理技術 の課題}

\section{1 下水道事業の推移と現況}

わが国の近代下水道事業は昭和33年の新下水道法の 制定に始ったといえる。昭和 38 年には，第 1 次下水道 整備 5 ケ年計画を発足させ, 以来現在の第 5 次 5 ケ年 計画に至まで数次にわたり計画を改定・実施してきた. 乙の間，下水道事業への投資規模は飛躍的拡大を見た が，乙乙数年は厳しい財政事情を反映して足踏み状態 である。

公共下水道事業を実施している市町村の数は昭和 59 年度末に挍いて 834 に達しているが, わが国の総市町 村3254の $1 / 4$ を占めているに過ぎない。てのうち 480 市町村で下水処理を実施している。 また，40都道府県 85箇所で流域下水道事業が実施されており, てのうち 43箇所で処理開始している. 乙の他にも, 農山漁村や 国立公園などの自然公園内の集落を対象として特定環

表 1 下水污泥の処分状況 (58.4.1 59.3.31)

\begin{tabular}{|r|r|r|r|r|c|}
\hline $\begin{array}{c}\text { 処分形態 } \\
\text { 処理性状 }\end{array}$ & 陸上埋立 & 海面埋立 & 有効利用 & そ の 他 & 計(\%) \\
\hline 脱 水 ケー -7 & 1,241 & 127 & 246 & 44 & $\begin{array}{c}1,658 \\
(75)\end{array}$ \\
\hline 焼 却 灰 & 229 & 75 & 30 & 0 & $\begin{array}{c}334 \\
(15)\end{array}$ \\
\hline 乾 燥 污 泥 & 10 & 0 & 30 & 0 & $\begin{array}{c}40 \\
(2)\end{array}$ \\
\hline 消化・濃縮污泥 & 2 & 0 & 4 & 168 & $\begin{array}{c}174 \\
(8)\end{array}$ \\
\hline 計 $(\%)$ & $\begin{array}{c}1,482 \\
(67)\end{array}$ & $\begin{array}{c}202 \\
(9)\end{array}$ & $\begin{array}{c}310 \\
(14)\end{array}$ & $\begin{array}{c}212 \\
(10)\end{array}$ & $\begin{array}{c}2,206 \\
(100)\end{array}$ \\
\hline
\end{tabular}

注）乾燥污泥には堆肥化污泥を含む. 


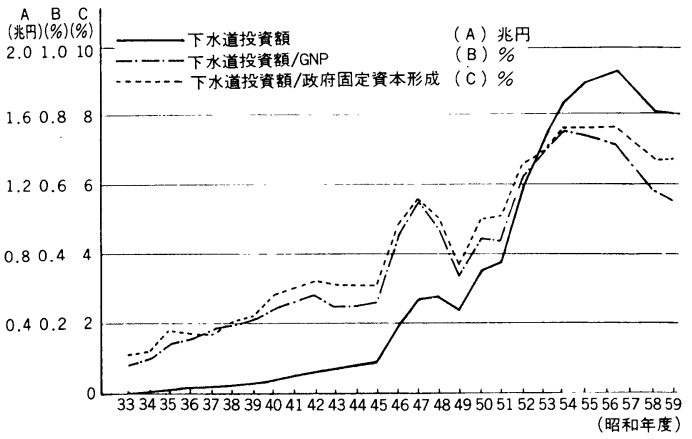

注）GNP及び政府固定資本形成の39年度以前は旧SNAによる

図-1 下水道投資の推移

境保全会公共下水道が94箇所で，また工場排水が全水 量の $2 / 3$ 以上を占める場合として特定公共下水道が 7 箇所で実施されている.

昭和 59 年度末における下水道の総人口普及率が $34 \%$ と, 三人に一人がその恩恵に浴する状況となり，い上 いよ下水道も「維持管理の時代に入った」といわれて いる。また，管渠延長も 9 万 8 千 kmとなっており，今 年度中に10万 $\mathrm{km}$ 突破することは確実となっている. てれは地球を二回り半できる距離であり, 今後とも毎 年 8 千 kmずつ延長されてゆくと予想されている.

一方，維持管理費がどれくらい支出されているかを 見てみると，公共下水道は58年度で 455 市町村 3072 億 円となっており, 流域下水道は25都道府県 266 億円と

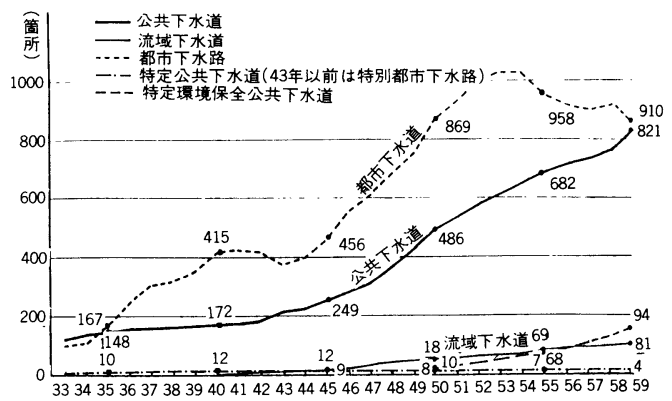

図-2 下水道事業実施箇所数の推移

着実に増加している.

下水道普及率の地域間格差む，下水道が大都市から 整備されていった歴史的な経緯により都市規模により 相当ばらついている，政令指定都市では普及率は約 80

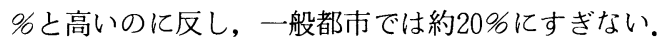
人口が比較的少ない地方都市にも下水道を普及させ, 地域間の格差を無くすことが急務となっている.

出来るだけ多くの人々に下水道の効用を理解しても らい，下水道事業を円滑に進めるため，建設省ではこ こ数年いくつかの施策を打ち出してきた。

表 2 はAquatopia（=Aqua Utopia）という下水 道のモデル事業の実施箇所とその事業内容を示してあ る.乙の事業では，最近都会から姿を消しつつある 「水辺の憩い」を取り戻すととが行われ，対象都市は 重点的に下水道事業の促進を図ることにしている。

図-3 日本の都市人口ランク別下水道実施状況

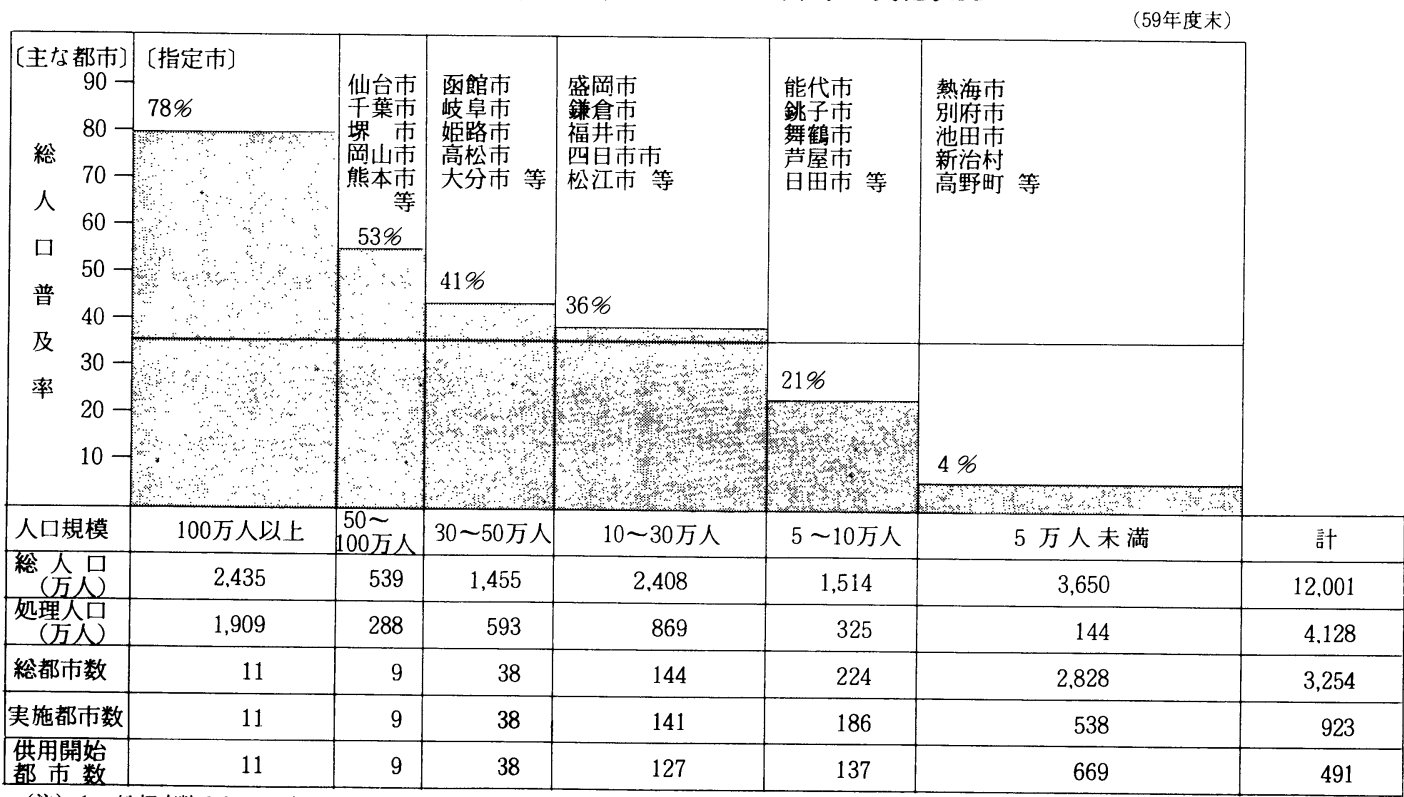

（注） 1. 総都市数 3,254 の内訳は，市 652 ，町 1,991 ，村 611 . (東京都区部は市に含む。)

2. 実施都市数は公共下水道之特定環境保全公共下水道の合計 
処理水を有効に活用することにより, 従来の下水道 施設の機能に更に新しい機能を付加することによって 市民生活を更に「アメニティ(快適)」なものにするて とを目的として「アメニティ下水道」モデル事業を実 施している. アメニティ下水道としては, 下記の 2 種 類がある.
(ア）「オープン水路のせせらぎの回復」

污泥した河川や故渴した都市内の水路に処理水を 導入し，せせらぎを回復する。

(1)「豪雪地帯における積雪のすみやかな排除」 公共下水道雨水渠や都市下水路に放流水を導水し 投入された雪をすみやかに排除する.

（59年度指定）

表 2 アクアトピア指定状況

\begin{tabular}{|c|c|c|c|}
\hline 県 名 & 都市名 & 主な水域名 & 内 \\
\hline 北海道 & $\begin{array}{l}\text { 中川郡 } \\
\text { 池田町 }\end{array}$ & 清見二線川 & 町内の水路を浄化し, 清見二線川の水質 \\
\hline 青森県 & 弘前市 & 土 㴊 川 & 市内の水路の水質を改善し, 鯉を放流し, 市民が水と親しむ場を創造する. \\
\hline 岩手県 & 盛岡市 & 中 津 川 & 町内の水路の水質改善を図り,「杜と水の都」盛岡の環境を保全する. \\
\hline 宮城県 & 松島町 & 松 島 湾 & $\begin{array}{l}\text { 町内の水路から松島湾に流入する污水を下水道により浄化し, 日本三景 “松島” } \\
\text { の周辺環境を保全する. }\end{array}$ \\
\hline 山形県 & 天童市 & 倉 津 川 & 市内の水路の水質浄化を行い, 鮎が泳ぐ市民の覟いの場を創造する. \\
\hline 茨城県 & $\begin{array}{l}\text { 行方郡 } \\
\text { 潮来町 }\end{array}$ & 潮 来 水郷 & 町内の堀割の水質浄化を行い, “アヤメと水郷” の環境を改善する. \\
\hline 群馬県 & $\begin{array}{l}\text { 群馬郡 } \\
\text { 榛名町 }\end{array}$ & 榛 名 湖 & $\begin{array}{l}\text { 町内の水路に清流を呼びもどし, 町民の貴重な財産である溙名湖の水質保全を } \\
\text { 図る. }\end{array}$ \\
\hline 岐阜県 & 高山市 & 川 & 市内の水路の水質改善を図り,“小京都”之呼ばれてている市民にとっては貴重な環境を保全する。 \\
\hline 静岡県 & 浜松市 & 浜名湖水系 & 市内の水路の水質改善を図り，市民が水と親しむ場を創造する. \\
\hline 大阪府 & 豊中市 & 市内河川 & $\begin{array}{l}\text { 利倉地区の人口水路にホタルの里を復活させるとともに, 市内の水路の水質改善 } \\
\text { を図り市民の款いの場にする. }\end{array}$ \\
\hline 島根県 & 松江市 & 大 橋 川 & “水の都”松江を復活させるために, 市内の水路の水質改善を図る. \\
\hline 岡山県 & 倉敷市 & 倉 敷 川 & $\begin{array}{l}\text { 市内の水路の水質改善を図り, 白壁とマッチする環境を作り, 市民が水と親しむ } \\
\text { 場を創造する. }\end{array}$ \\
\hline 岡山県 & 岡山市 & $川$ & 市内の水路の水質改善を図り, 緑の水辺等の市民の憩いの場を創造する. \\
\hline 山口県 & 萩 市 & 新 堀 川 & $\begin{array}{l}\text { 市内の水路の水質改善を図り, 市民にとっては貴重な城下町, 萩の環境を回復す } \\
\text { る. }\end{array}$ \\
\hline 福岡県 & 柳川市 & 柳川 水郷 & 市内の水路の水質を改善し, 市民の財産である白秋ゆかりの水郷を復元する. \\
\hline 熊本県 & 人吉市 & 山田 川 & $\begin{array}{l}\text { 川下りで有名な球磨川の水質保全を図るととむに，市内の水路の水質改善を図り, } \\
\text { 市民に秘いの場を提供する. }\end{array}$ \\
\hline 大分県 & 日田市 & 筑 後 川 & $\begin{array}{l}\text { 市内の水路に清流を呼びもどし, 九州の小京都と呼ばれてきた山紫水明の地「日 } \\
\text { 田」を復活させ, アャメと鯉の里を創造する. }\end{array}$ \\
\hline
\end{tabular}

（60年度指定）

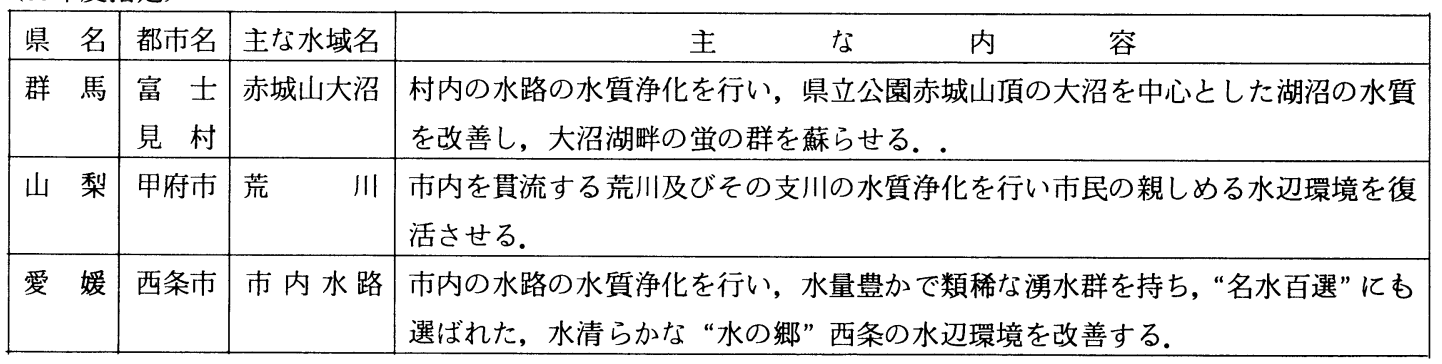


表 3

(ア)「オープン水路のせせらぎの回復」

\begin{tabular}{|c|c|c|c|}
\hline 京都府 & 長岡京市 & 勝竜寺都市下水路 & 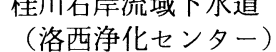 \\
\hline 分県 & 大分市 & 中島 1 号雨水幹線 & （弁天終末処理場） \\
\hline
\end{tabular}

(イ)「豪雪地帯における積雪のすみやかな排除」

北海道 江 別市 江別32号雨水幹線 (江別終末処理場)

青森県 青 森 市 浪打雨水幹線 （八重田終末処理場）

表 4 昭和 60 年度採択アピール下水道

\begin{tabular}{|c|c|c|c|}
\hline 府県名 & 市町村名 & 称 & 内 \\
\hline 埼 玉 & 日 高 町 & $\begin{array}{l}\text { “清流の宝石”カ } \\
\text { ワセミを守る下水 } \\
\text { 道 }\end{array}$ & $\begin{array}{l}\text { 高麗川周辺に生息するカワセミは, “清流の宝石” と屯いわれている美し } \\
\text { い鳥であるが, 近年の河川の水質の悪化によりその餌となる小魚ととも } \\
\text { に減少している. 下水道整備により, この水域の水質を保全し, カワセ } \\
\text { ミの生息にふさわしい環境を守る. }\end{array}$ \\
\hline 富 山 & 高 岡 町 & スノーレス下水路 & $\begin{array}{l}\text { 高岡市は, 有数の豪雪地帯であり, 積雪は市民生活に他地域との大きな } \\
\text { ギャップを生じさせている. このため, 都市下水路に流雪機能を持たせ } \\
\text { ることにより, 市街地の除排雪を行い雪に強いまちづくりを推進する. }\end{array}$ \\
\hline 富 山 & 分尾町 & スノーレス下水路 & $\begin{array}{l}\text { 八尾町は, 有数の豪雪地帯であり, 積雪は市民生活に他地域との大きな } \\
\text { ギャップを生じさせている. このため, 都市下水路に流雪機能を持たせ } \\
\text { ることにより, 市街地の除排雪を行い雪に強いまちづくりを推進する. }\end{array}$ \\
\hline 大 阪 & 大阪市 & なにわ大放水路 & $\begin{array}{l}\text { 大阪市東南部に拀てて, 急速な市街化の進展による雨水流出量の増大 } \\
\text { 等により, 大きな浸水被害が発生している. 乙の抜本的な対策として, } \\
\text { 平野〜住之江幹線を建設し, 浸水地区の雨水を大阪湾付近まで導水し, } \\
\text { 排水する. }\end{array}$ \\
\hline 広 島 & 府 中 町 & $\begin{array}{l}\text { 孛侌の国府浸水制 } \\
\text { 御作戦 }\end{array}$ & $\begin{array}{l}\text { 雨水流出量の増大のため排水能力が不足となったポンプ場を増設せずに, } \\
\text { 雨水調整池を設けて眝留を行い, 浸水の解消を図る. 晴天時はオープン } \\
\text { スペースとして住民が利用できるようにする. }\end{array}$ \\
\hline 山口 & 下関市 & $\begin{array}{l}\text { ふぐも生きいき下 } \\
\text { 水道 }\end{array}$ & $\begin{array}{l}\text { ふぐの水揚量全国一の下関では, 水産市場付近の海域より直接生魚槽へ } \\
\text { 海水を取水している. 早急に下水道を整備し, 付近の海域の水質を保全 } \\
\text { するととにより,「生き」の良いふぐを守る. }\end{array}$ \\
\hline 熊 本 & 熊 本 市 & \begin{tabular}{|l|} 
峃定津湖クリーン作 \\
戦
\end{tabular} & $\begin{array}{l}\text { 江津湖は, 水前寺公園と一体とする公園整備事業が進められているが, } \\
\text { 近年その水質は周辺からの生活雑排水により污濁している公共下水道の } \\
\text { 整備によりこの水質を改善し, 市民が水と親しめるうるおいのある場を } \\
\text { 創造する. }\end{array}$ \\
\hline 熊 本 & 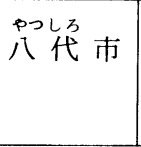 & 八代麓川眝水作戦 & $\begin{array}{l}\text { 浸水解消のための都市下水路整備の際水路に眝水能力をあたせ, ポンプ } \\
\text { 施設なしに雨水排除ができるようにする. また, 水路周辺を歴史自然遊 } \\
\text { 歩道として整備し, 水辺に親しめる場をつくる. }\end{array}$ \\
\hline
\end{tabular}

アメニティモデル事業は全国 4 ケ所で実施している.

このほか, アピール下水道, アイデア下水道, 下水 処理水を雑用水として供給し水資源のひっ迫を緩和す る下水処理水循環利用モデル事業など, 下水道を多角 的に利用してゆき時代の複雑化に対応して多種多様な ニーズに応えるべく数多くの努力を行っている.

\section{2 下水処理の現状と課題}

昭和58年度末に颃いて全国で 584 箇所の下水処理場 が稼動しているが，乙れを処理方式別に分類したもの が表 6 である. ての表からあわかるように, 圧倒的に 多くの処理場が活性污泥法およびその変法を採用して いる. 活性污泥法はそれ以前の処理方式に対して優位 
表 5 昭和 60 年度採択アイデア下水道

\begin{tabular}{|c|c|c|c|}
\hline 府県名 & 市町村名 & 称 & 内 \\
\hline 新 潟 & $\begin{array}{l}\text { あらい } \\
\text { 新井市 }\end{array}$ & $\begin{array}{l}\text { 雪国のくらしを変 } \\
\text { える } \\
\text { 融雪雨水排水路 }\end{array}$ & $\begin{array}{l}\text { 新井市は, 全国有数の豪雪地帯であり, 冬期間の雪処理に効果を発揮す } \\
\text { る流雪溝の整備を望む声が強い. そこで, 公共下水道の雨水開渠を, グ } \\
\text { レーチングとせき板による融雪雨水排水路として整備し, 雪に強い街づ } \\
\text { くりの一環とする. }\end{array}$ \\
\hline 富 山 & $\begin{array}{l}\text { なタりがわ } \\
\text { 滑川市 }\end{array}$ & $\begin{array}{l}\text { 鮎・鯉の泳ぐ都市 } \\
\text { 下水路 }\end{array}$ & $\begin{array}{l}\text { 浸水解消のため都市下水路を整備する際に, 現在生息している魚類を保 } \\
\text { 護するため, 水路に落差工や魚巣ブロック等を設置する. }\end{array}$ \\
\hline 大 阪 & 八尾市 & $\begin{array}{l}\text { 浸水をなくす飛行 } \\
\text { 場地下道の再利用 }\end{array}$ & $\begin{array}{l}\text { 空港下を通っていた地下道が平面道路となるので, この地下道を下水道 } \\
\text { の雨水貯留地として再利用し, 周辺の浸水解消に役立てる. トンネル区 } \\
\text { 間はそのまま利用し, 堀割区間は, コンクリートボックス構造とする. }\end{array}$ \\
\hline
\end{tabular}

であるととは疑いの余地のないとてろであるが，わが 国の固有の条件から照らすと次のような問題点が指摘 される.

第一に, 活性污泥法は処理規模が小さくなると, 工 ネルギー効率が低下するというととである．既に述べ たように，わが国の乙れからの下水道の普及は比較的 小規模な地方都市が主流となっていくので, 経済的に む，また国家安全保障的意味でも省エネルギー策をす すめ, 小規模化に伴うエネルギー効摔の低下の問題を 解決してゆかねばならない。

第二に, 国土が狭小なわが国では, 污泥の処理好分 が他の国に見られない程重要な意味を持っているとと である. 事実, 污泥処分場の延命化および他に有効な
手段がないことのため污泥の焼却は全国で最終処分量

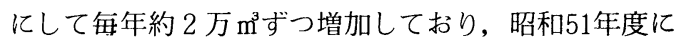
は全最終処分量のうち焼却量は $9 \%$ に過ぎなかったが, 昭和58年には15\%とシェアを拡大している，焼却のた めに要する重油は昭和 58 年度で全国で約 5 万 6 千 $\mathrm{m}^{3}$ （日本下水道協会調べ）に達し重油 $1 \ell 80$ 円とすれば, 45億円にものぼる勘定となる．乙れを脱水前の状態で みると $50 \%$ が焼却処理となっている。（昭和 56 年建設 省土木研究所調べ)

第三に，下水処理水を放流する水域が，晴天時には 流量の少ない河川とか内陸の水域に制限される事例が 多々ある.乙の他, 河川や湖沼の富栄養化を防ぐため 高度な栄養塩類の除去が必要となってきている．活性

表 6 処処理方式別処理場数

(昭和 58 年度)

\begin{tabular}{|c|c|c|c|c|c|c|c|c|c|c|c|}
\hline \multirow[b]{2}{*}{$\begin{array}{l}\text { 計画晴天時 } \\
\text { 日最大処理 } \\
\text { 水量 }\left(千 \mathrm{~m}^{3} / \text { 日) }\right.\end{array}$} & 簡易 & 中 & 級 & \multicolumn{4}{|c|}{ 高 } & \multicolumn{3}{|c|}{ 級 } & \multirow[b]{2}{*}{ 計 } \\
\hline & $\begin{array}{l}\text { 沈 } \\
\text { 殿 } \\
\text { 池 }\end{array}$ & $\begin{array}{l}\text { 高 } \\
\text { 速 } \\
\text { 散 } \\
\text { 水 } \\
\text { 洰 } \\
\text { 床 } \\
\text { 法 }\end{array}$ & $\begin{array}{l}\text { 高 } \exists \\
\text { 速 } \\
\text { エ沈 } \\
\text { ア 殿 } \\
レ \text { 池 } \\
\text { シ }\end{array}$ & $\begin{array}{l}\text { 標 } \\
\text { 準 } \\
\text { 活 } \\
\text { 性 } \\
\text { 涺 } \\
\text { 法 }\end{array}$ & 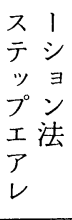 & $\begin{array}{l}\text { 長 シ } \\
\text { 都 } \\
\text { 間 光 } \\
\text { エ法 } \\
\text { ア } \\
\text { レ } \\
\text { I }\end{array}$ & 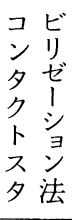 & $\begin{array}{l}\text { 酸 } \\
\text { 素 } \\
\text { 恬 } \\
\text { 活 } \\
\text { 泥 } \\
\text { 法 }\end{array}$ & $\begin{array}{l}\text { オン } \\
\text { キデ } \\
シ 1 \\
\text { デッ } \\
\text { ィチ } \\
シ \\
\exists\end{array}$ & $\begin{array}{l}\text { 回 } \\
\text { 転 } \\
\text { 生 } \\
\text { 物 } \\
\text { 接 } \\
\text { 触 } \\
\text { 法 }\end{array}$ & \\
\hline 5未満 & 1 & 2 & 3 & 38 & 4 & 12 & 2 & & 6 & 7 & 75 \\
\hline $5 \sim 10$ & 1 & 4 & & 44 & 5 & 1 & & 1 & 1 & 3 & 74 \\
\hline $10 \sim 50$ & 2 & 5 & 13 & 135 & 18 & 2 & & 1 & & 3 & 167 \\
\hline $50 \sim 100$ & & 1 & 2 & 71 & 18 & & & 1 & & 1 & 93 \\
\hline $100 \sim 500$ & & & 1 & 96 & 22 & & & 2 & & & 120 \\
\hline 500以上 & & & & 12 & 7 & & & & & & 19 \\
\hline 計 & 4 & 12 & 19 & 396 & 74 & 15 & 2 & 5 & 7 & 14 & 548 \\
\hline
\end{tabular}

注） 1. 処理場において二つ以上の処理方式をむつ場合は, 処理水量の大きい処理方式とした.
2. 合計 548 処理場の内訳 $\left\{\begin{array}{lr}\text { 公共下水道 } & 478 \\ \text { 流域下水道 } & 47 \\ \text { 特定公共下水道 } & 9 \\ \text { 特定環境保全公共下水道 } & 14\end{array}\right.$ 
污泥法では必らずしも安定性が十分とは言えない。さ らに場所によっては化学的酸素要求量 (COD)が放流 水基準として用いられているとてろがあるが，乙の場 合には活性污泥法で対応するためには，十分な管理が 必要な場合が多い。

第四に，下水処理水を水資源として再利用する場合， 難分解性物質や窒素・リンの残存, 処理水の着色, 疫 学上の安全性未確認などの理由からその用途は大幅な 制限を受けている。わが国では大都市圈を中心として 毎年水資源不足が問題亡なって扔り, 従来からの手段 による水源開発も適地が残り少なくコスト高となって きている，乙の問題を緩和する有力な方法として下水 処理水を再利用することがある.

污泥の処理という観点からも, 重金属含有污泥の対 策, 嫌気性污泥消化プロセスの改善, コンポストプロ セスの改善等の枚挙にいとまがない。

以上のような現在のシステムの問題点, あるいは研 究開発課題の認識が原動力となってバイオフォーカス WT の研究開発プロジェクトが発足する運びとなった わけである.

\section{2. バイオテクノロジーを活用した新排水処理 システムの開発（バイオフォーカスWT）}

\section{1 バイオフォーカスWTの概要}

バイオテクノロジーあるいはバイオエンジニアリン グという用語が唱えはじめられたのは，せいぜい十数 年前からであり，その定義は現在に扔いても定まって いない。しかしながら，バイオテクノロジーを広義に 解釈すれば,

「生物の生命維持機能を人間のために利用する技術」 とすることが出来よう，すなわち，生命現象の基礎研 究の成果に基づき, 生物あるいはその一部の機能を活 用することにより我々の生活を豊かにするのがバイオ テクノロジーであると言える．従って現在我々が排水 処理のために生物学的な処理プロセスを利用している ということは，広義な意味でのバイオテクノロジーの 活用と言うことができる．既存のあのから新しいもの まで含めてバイオテクノロジーを排水処理に適用する とき, 第一歩となる最あ重要なととは問題の性格を正 確に把握し, 問題解決の手法を基にして問題の分類を 行うことである.

バイオフォーカスWTのプロジェクトの基本的戦略 は, 図-4に示すように現在の下水処理・污泥処理の問 題を以下の 3 種類に大別することから始まる.

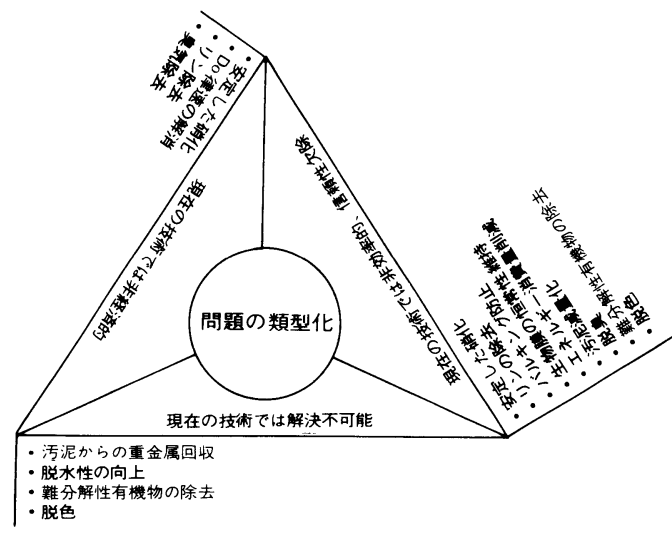

図-4 現在の下水処理技術に関する問題の例とその 類型化

(1) 現在の技術では非経済的

(2) 現在の技術では不安定（信頼性が十分でない）或 いは効果的でない.

(3) 現在の技術では解決不可能

問題の類型化之同時に解決方法について屯分類が可 能であり，次のような 4 つに分類することができる.

(1) 既存技術の改善

(2) 他分野の技術の応用（技術移転）

(3) 未だ利用されていない微生物の探索と排水処理へ の適用法の開発

(4) 遺伝子制御による微生物の改良

現在まで広範囲な実用化をみた技術として既存技術 をとらえれば，浮遊生物学的な排水処理プロセスとし ての活性污泥法, 生物膜プロセスとしての散水 3 床法, 回転円板法, さらに污泥処理プロセスとして浮遊生物 型好気性污泥消化プロセス, 浮遊生物型嫌気性污泥消 化プロセスなどが既存技術として列挙される。

バイオフォーカスWTプロジェクトは，乙のような 既存技術の改善については別のプロジェクトに譲り, それ以外の解決法の研究開発及び実用化に焦点をあて ている.

資料 I は，バイオフォーカスWTの全体研究課題を 示したものである。

第一番目の「醅素・微生物の固定化技術の開発」で は, 既に発酵工業・医薬品製造工業において実用化し ている技術を，排水処理の分野に移転しょうとするす のである. 細砂, 粒状活性炭を用いた流動床型生物反 応槽の開発は世界的に行われているが, この研究では 担体総合法での担体素材の開発から手がける予定であ る. さらに, 包括型の固定化法についても研究開発を 
行う予定である.

また，酵素の固定化の応用技術の一つとしてバイオ センサーが挙げられ, より安定性の高い水質計測用セ ンサーの開発を行う。

第二番目の「醅素・微生物バンクの開発」では未利 用の微生物の探索・培養を行い排水処理への適用手法 を研究する，さらに，現在特殊な能力を有する菌（た とえば硝化菌，メタン生成菌，光合成細菌等）につい ては, 固定化手法を用いて大量培養する方法の研究を 行う。

未利用の微生物の探索については, 通常の自然界之 同時に過酷な環境中に生息している微生物の探索に力 点を置く予定である.

第三番目の「遺伝子操作による処理生物種の開発」 では，特殊能力を有する細菌を対象にして，それらの 能力に対応する DNA コードの解明が急務である。現 在重金属耐性菌を主体として DNA コードの解明の研 究を行っている. 乙の研究と同時に, 細胞内組換えに よって出現した変異株の分離あ行う予定である.

以上の 3 つの研究テーマはバイオリアクターに関連 したあのであるが，実際の排水処理においては物理・ 化学的プロセスも必要である. 四番目, 五番目の研究 課題では，新しく開発されたバイオリアクターと物性 ・化学的プロセスを組み合わせて全体の排水処理シス テムの開発及びその試験運転を行う。

\section{2 共同研究制度}

バイオフォーカスWTは, 排水処理に対してある種 の革命的な役割を果たすすのである，また，従来の下 水処理への異種技術の導入でああるので, このプロジ ェクトを建設省のみで実施するのでは限界があり，公 社・公団・地方自治体，民間企業などと共同研究を行 ってプロジェクトの推進を図る，乙のため「建設省研 究所等共同研究実施規定」の改正を1985年 6 月に行っ た。

本改正では, 共同研究の相手方として, 従来は国家 機関，公共団体，公団および建設大臣の設立許可を受 けた法人に実質上限られていたすのを民間企業まで拡 大したあのである。乙れに伴って共同研究参加の民間 企業に対して共同研究の結果得られた国の所有する特 許, 実用新案について, 共同研究の終了から 5 年を越 えない範囲で「優先実施権」を与えることができると している．また，共同特許出願の持ち分については, 研究の貢献度に応じ両者の協議により決定する。乙の ような考え方は，徒らに企業間の競争を扇りたてると
いう反論もあったが，建設省としてよりよい技術を積 極的に公共事業に取り入れていくという姿勢を明確に した点で，乙の考え方を歓迎する企業は多い。 共同研究には,

(1) 建設省が共同研究の相手を指定する場合 乙の場合の相手は, 国立研究機関, 地方公共団体, 公社・公団，業界を代表する協会に限られる.

(2) 共同研究の相手を指定しない場合

この場合には，建設省土木研究所或は建築研究所 の所長が共同研究の相手を公募する，公募してきた 企業については，その企業の研究実施能力等を判断 するための審查会を設置し，共同研究の相手の選定 を行う。バイオフォーカスWT はこの項目による方 式で共同研究をスタートさせた。

このほか，民間等からの提案によって研究所等の所 長が適当と認めた場合も行うことができる，民間から のプロポーザルについては研究所等の長が指定する機 関に設けられた学識経験者による審査委員会で審査を 行い，研究所の長が同審査委員の意見を参考に選定す る.

\section{3 バイオフォーカスの最近の動き}

バイオフォ一カス WT た審査委員会及び建設省土木研究所の審查会に扔いて 共同研究の相手方企業を去る10月23日に決定した。各 研究テーマでとの共同研究企業は表 7 のとおりである. 各企業とは共同研究に関する協定を結び共同研究を開 始する。.

また，乙れら共同研究を総合的な見地から調查・指 導・検討・審査していく機関として(財)国土開発技術 センター内に学識経験者を中心とする「システム開発 委員会」を設置した．その仕組は図-5，6亿，委員会 のメンバーは表 8 亿示す。同委員会の下に「バイオリ アクター開発部会」と「酵素・微生物バンク開発部会」 を，それぞれに幹事会を設置し研究体制を固めた。活 動状況としては, システム委員会を 1 回, 各部会を 1 回, 幹事会をそれぞれ 2 回昭和 60 年内に開き研究の具 体的な研究方針と開発目標を検討している。

バイオフォーカスWTのテーマの一部は日本下水道 事業団に委託され, 事業団の共同研究規定に従って中 間 2 社と表 9 のと抢り共同研究に入っている.

バイオフォーカス WTは昭和60年度をスタートとし て 5 ケ年間に 30 億円を投入する計画で本年度はまず 1 億 3 百万円が計上されている．昭和 61 年度は 1 億 3 千 万円が最終内示されたほか, 土木研究所に新下水処理 


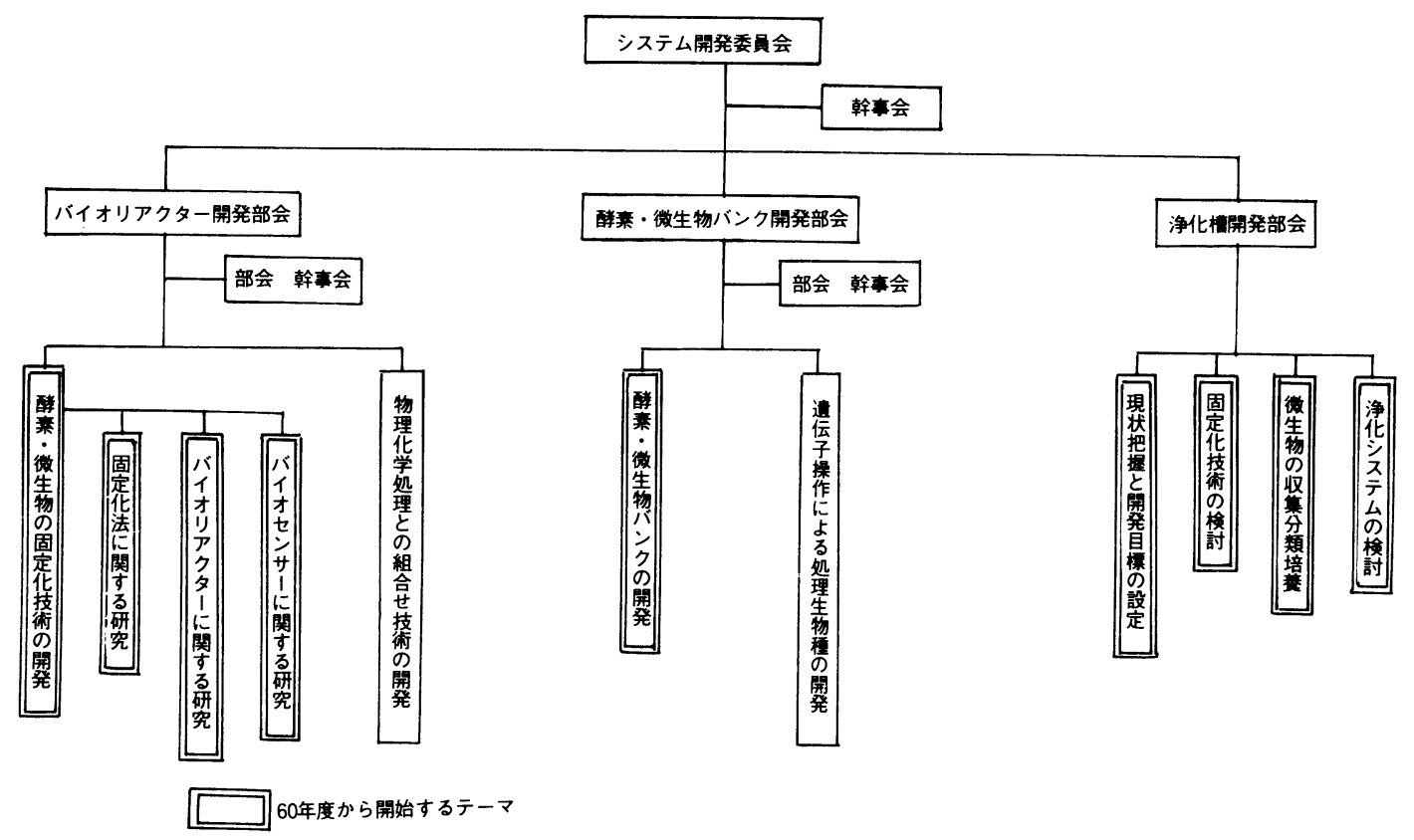

バイオテクノロジーを活用した新廃水処理システムの開発委員会構成及び研究分担（案）

図-5 総合技術開発プロジェクト

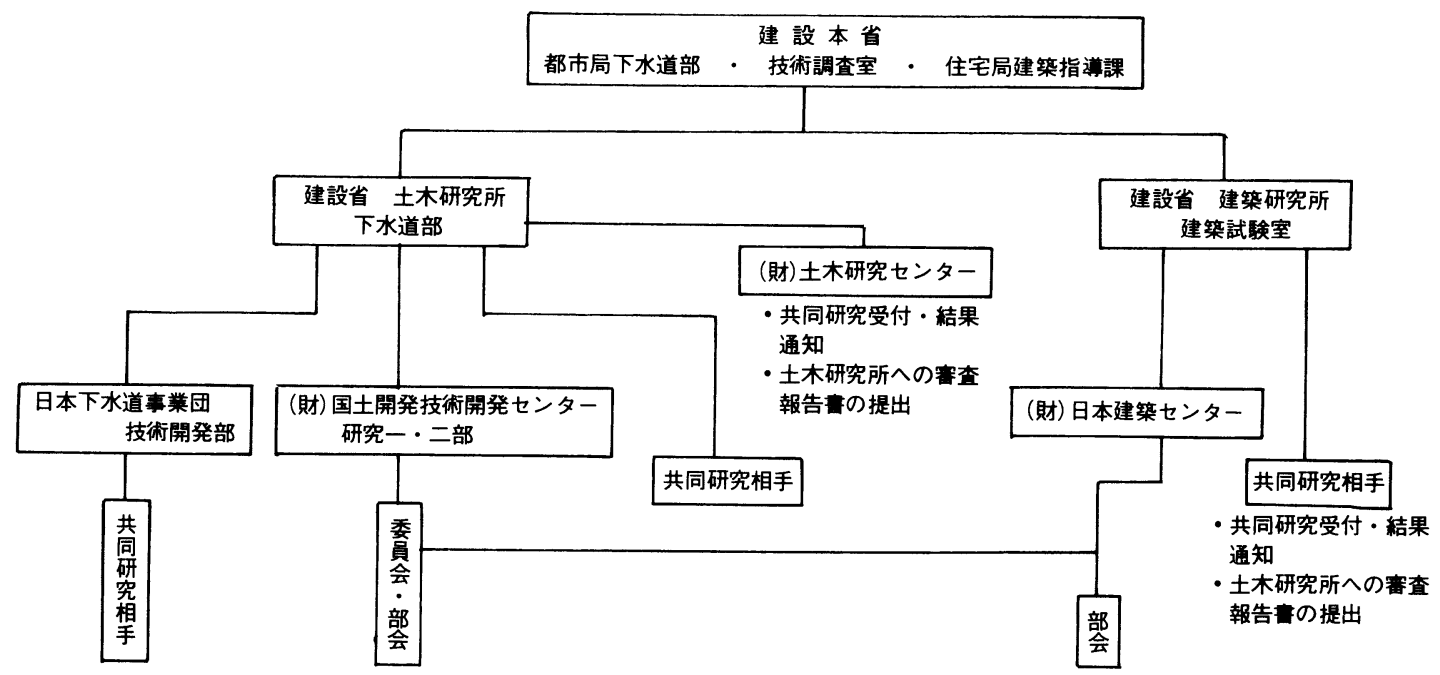

バイオテクノロジーを活用した新廃水処理システムの開発関係機関構成図

図-6 総合技術開発プロジェクト

主任研究官が新設される見込である．今後，プロジェ クトがフレーム作りからハードウエアを伴う実務研究 レベルへと移行するにしたがって予算を増加させてゆ く予定である.

3. おわりに

今回の共同研究規定の改正により, 建設省土木研究
所が企業と 1 対 1 で共同研究できるようになったため, 企業の持つ技術力の蓄積やノウハウ, 研究開発能力が 競争他社に流れる心配がなく遺憾なく発揮できる. こ れまで建設省が企業と共同研究する場合に一部の企業 に偏ることなく公平であることを重視するあまり，優 れた能力を持つ企業を選択的に採用し優秀な成果を得 てもってその利益を国民に還元することに慎重となり 


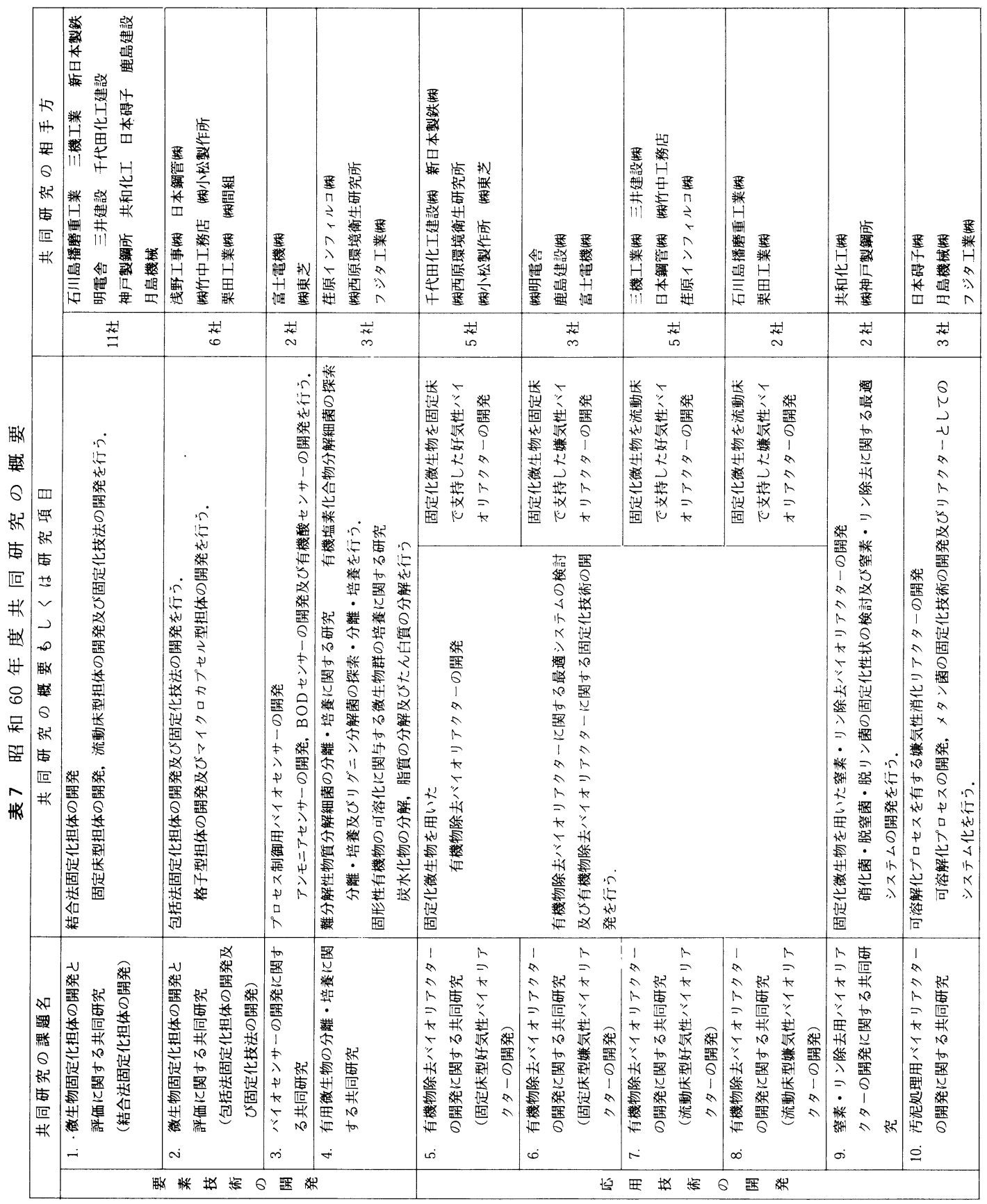

がちであった。しかし，今後は優秀な企業の技術開発 意欲を刺激しその成果に見合った特典を明確にするこ とにより結果として経済的な下水道を実現するととも に業界全体のレベルアップを目指すあのである.

下水処理は流入してくる下水の組成は明らかでなく 水量も一定でない. しかもいずれあコントロールする ことはできない. また, 処理に使われている活性污泥 等に住む微生物種もはっきりしない. 原料もプロセス
あ一定でなく不明確であることは工業プロセスに比べ て不利な条件である。 バイオテクノロジーは発酵工業 ・医薬品工業を舞台として発達してきたが, 下水処理 分野に適用する場合には幾多の困難を乗り越えてゆか ねばならない.しかし，バイオテクノロジーが急速に 発達しつつあり, 他方, 下水道普及率が今だに $34 \%$ に すぎない今とそ21世紀の下水道の礎を築くべき格好の 時機に来ているといえる. 
表 8-1 バイオテクノロジーを活用した新排水処理 システム開発委員会

\begin{tabular}{|c|c|c|c|c|}
\hline 委員長 & 橋本 & 奨 & 大阪大学工学部 & 教授 \\
\hline 委 員 & 柏谷 & 衛 & 東京理科大学理工学部 & 教授 \\
\hline " & 軽部 & 征夫 & $\begin{array}{l}\text { 東京工業大学資源化学研究 } \\
\text { 所 }\end{array}$ & 教授 \\
\hline " & 栗原 & 康 & 東北大学理学部 & 教授 \\
\hline " & 戸田 & 清 & 東京大学沁用微生物研究所 & 教授 \\
\hline " & 武藤 & 暢夫 & 関東学院大学工学部 & 教授 \\
\hline " & 杉本 & 一次 & $\begin{array}{l}\text { 東京都下水道局西部管理事 } \\
\text { 務所落合処理場 }\end{array}$ & 所長 \\
\hline " & 栗林 & 宗人 & $\begin{array}{l}\text { 日本下水道事業団技術開発 } \\
\text { 研修本部技術開発部 }\end{array}$ & 部長 \\
\hline \multicolumn{5}{|c|}{ 委託者側 } \\
\hline 委 員 & 岩井 & 國臣 & 建設省大臣官房技術調查室 & 室長 \\
\hline " & 安田 & 武臣 & $\begin{array}{l}\text { " 都市局下水道部下水 } \\
\text { 道企画課 }\end{array}$ & 課長 \\
\hline$"$ & 辻 & 栄一 & $\begin{array}{c}\text { 下水道課 } \\
\text { " }\end{array}$ & 課長 \\
\hline " & 立石 & 真 & " 住宅局建築指導課 & 課長 \\
\hline " & 成田 & 信之 & " 土木研究所 & 研究調整官 \\
\hline " & 安藤 & 茂 & " 下水道部 & 部長 \\
\hline " & 浅野 & 賢二 & $\begin{array}{l}\text { "室 建築研究所建築試験 } \\
\end{array}$ & 室長 \\
\hline \multicolumn{5}{|c|}{ 受託者側 } \\
\hline 委 員 & 飯田喜 & 䇾 郎 & $\begin{array}{l}\text { (財) 日本建築センター評定 } \\
\text { 部構造課・設備課 }\end{array}$ & 課長 \\
\hline$"$ & 大田 & 敏彦 & $\begin{array}{l}\text { (財)国土開発技術研究セン } \\
\text { タ- }\end{array}$ & 理事 \\
\hline " & 戸谷 & 英世 & 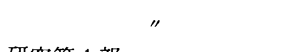 & 部長 \\
\hline$"$ & 山标 & 和也 & 研究第 1 部 & \\
\hline " & 飯島 & 尚 & " & $\begin{array}{l}\text { 理事 } \\
\text { 部長 }\end{array}$ \\
\hline & & & 研究第 2 部 & \\
\hline
\end{tabular}

表 8-2 バイオリアクター開発部会

\begin{tabular}{|c|c|c|c|c|}
\hline 部会長 & 柏谷 & 衛 & 東京理科大学理工学部 & 教授 \\
\hline 委 員 & 軽部 & 征夫 & $\begin{array}{l}\text { 東京工業大学資源化学研究 } \\
\text { 所 }\end{array}$ & 教授 \\
\hline " & 鮫島 & 廣年 & 協和発酵工業怢 & 常務取締役 \\
\hline " & 松尾 & 友矩 & 東京大学工学部 & 教授 \\
\hline " & 宗宮 & 功 & 京都大学工学部 & 教授 \\
\hline " & 杉本 & 一次 & $\begin{array}{l}\text { 東京都下水道局西部管理事 } \\
\text { 務所落合処理場 }\end{array}$ & 所長 \\
\hline " & 富沢 & 健二 & $\begin{array}{l}\text { 日本下水道事業団技術開発 } \\
\text { 研修本部技術開発部 }\end{array}$ & $\begin{array}{l}\text { 総括主任研 } \\
\text { 究員 }\end{array}$ \\
\hline \multicolumn{5}{|c|}{ 委託者側 } \\
\hline 委 員 & 藤本 & 保 & 建設省大臣官房技術調查室 & 技術調査官 \\
\hline " & 浦田 & 健一 & $\begin{array}{l}\text { " 都市局下水道部下水 } \\
\text { 道企画課 }\end{array}$ & 課長補佐 \\
\hline " & 曽小川 & |久貴 & $\begin{array}{l}\text { 建設省都市局下水道部公共 } \\
\text { 下水道課 }\end{array}$ & 課長補佐 \\
\hline$"$ & 松川 & 隆行 & "＼cjkstart住宅局建築指導課 & 課長補佐 \\
\hline$"$ & 中村 & 栄一 & $\begin{array}{l}\text { " 土木研究所下水道部 } \\
\text { 下水道研究室 }\end{array}$ & 室長 \\
\hline " & 佐藤 & 和明 & 三次処理研究室 & 室長 \\
\hline$"$ & 京才 & 俊則 & 污泥研究室 & 室長 \\
\hline$"$ & 安中 & 徳二 & 水質研究室" & 室長 \\
\hline
\end{tabular}

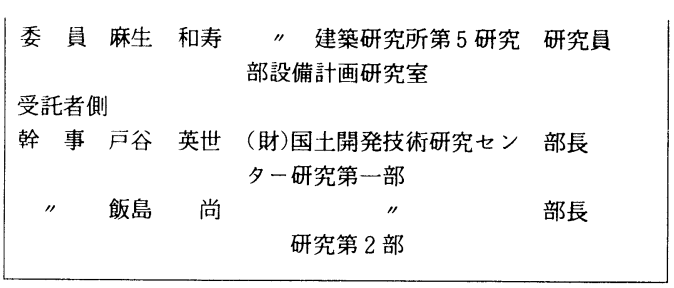

表 8 -3 酵素・微生物バンク開発部会

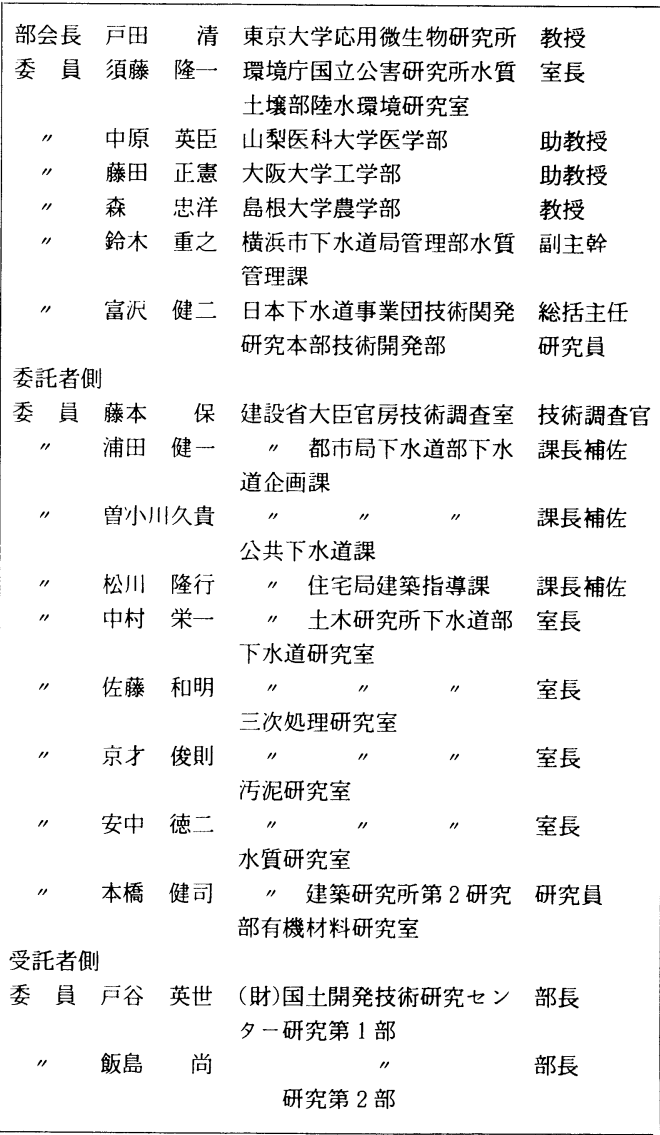

料資 I バイオテクノロジーを活用した新廃水処理 システムの開発プロジェクト研究課題

\section{1. 酵素・微生物の固定化技術の開発}

(1) 固定化方法に関する研究

排水処理施設のコンパクト化，施設運転費の軽減を 図るためには, 反応槽内の微生物濃度を大幅に増加さ せることが必要である。乙のため新たに固定化技術の 開発を図り，排水等の処理プロセスへの適用手法を研 究し, 指針化を図る。

(2) バイオリアクターに関する研究

生物分解性有機物（BOD発現物質）の急速分解, 硝化 (アンモニアの酸化), リンの過剩吸収 (脱リン), メタン発酵などに関与する微生物を新しく開発された 
表 9 昭和60年度共同研究の概要

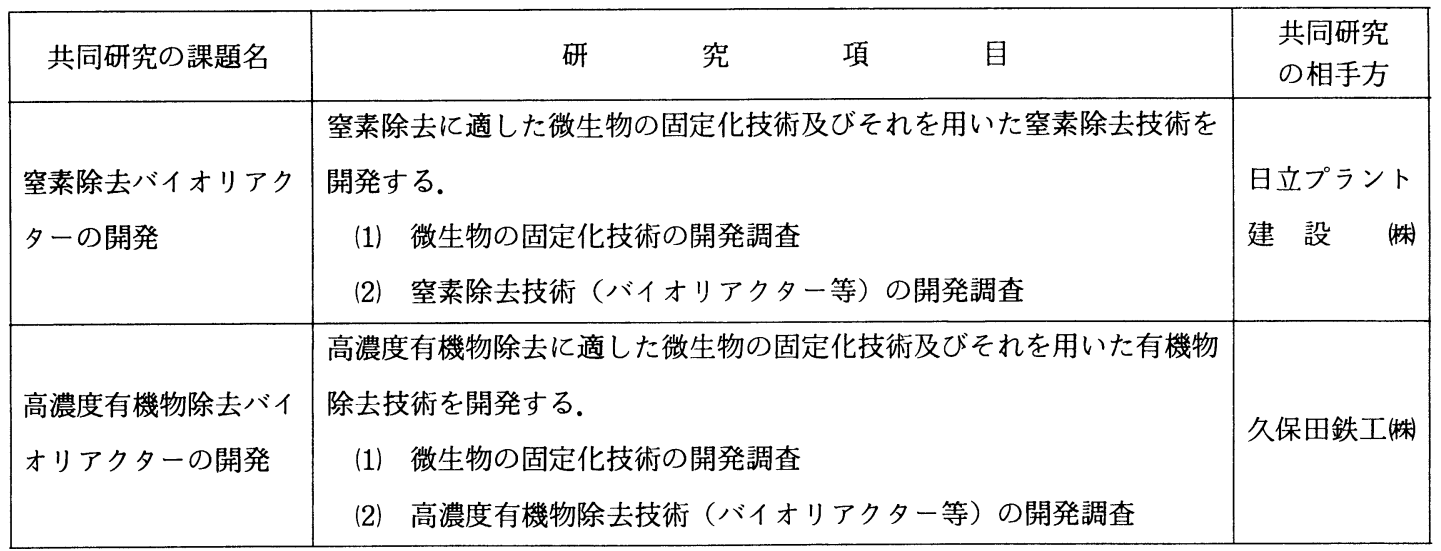

固定化技術を用いて固定化し，実排水を用いた室内実 験によって問題点の把握と解決策の立案を行う.さら 亿実験結果を解析し，固定化によって高濃度微生物を 保持したバイオリアクターの設計便覧（技術資料集） を作成する。

(3) バイオセンサーに関する研究

䤉素及びある種の微生物は, 常温, 常圧のもとで短 時間に物質の化学変化を起し，しかもその物質が特定 されるという基質特異性を持っている．乙の性質を利 用したバイオセンサーは, 在来の分析化学では考えら れなかった短い時間と少量の試料で，水中の特定物質 を検知・定量するてとができる，乙てでは，特定施設 からの排水を監視するバイオセンサー及び処理プロセ ス制御用のバイオセンサー開発に必要な基礎的研究を 行い試作器の製作・評価を行う。

\section{2. 酵素・微生物バンクの開発}

(1) 微生物の分離および分類に関する研究

処理水質の向上あるいは排水中から有価資源を回収 するためには，そのような能力を有する微生物を分離 ・分類し, 保存する必要がある．乙のため有用株を確 保する研究を行う。

なお，既存の微生物バンクの有効利用を図るため, 建設省以外の研究機関之の相互協力を進め, 排水処理 に有用な微生物バンク情報のシステム化す研究する.

(2) 酵素の評価関する研究

酵素は常温・常圧という自然の条件下で諸々の反応 を促進することができる.

従って微生物ではなく酵素を直接排水処理等に用い ることが出来れば，より短時間に，複作的反応を伴う ことなしに排水処理・有価物の回収が行える，乙のた め排水処理に関与している微生物から所要の酵素を抽
出し, 生化学的特性, 量産化の研究を行う。さらに醅 素を用いた排水処理・有価物回収実験によって直接醉 素利用法の研究を行う。

(3) 酵素・微生物の保存及び大量培養に関する研究 高濃度微生物による排水処理施設のコンパクト化, 有価物の回収などを支援するためにはそれらに関与し ている醭素・微生物の保存法と大量培養法の技術を確 立して扔く必要がある。乙のため保存法実験によって 最適保存法を確立するための研究之, 酵素・微生物の 活性に関与する物理・化学的因子等を検討し大量培養 法を開発するための研究を実施する.

\section{3. 遗伝子操作による処理生物種の開発}

（1）遺伝子操作を行った生物種の排水処理への適用に 関する研究

遺伝子組換え，細胞融合などによって造られた微生 物種は，排水処理のような混合培養系では容易に淘太 されてしまうので, 新微生物種の至的環境条件を見い 出しておく必要がある。逆に，新微生物が既成の微生 物生態系に与える影響を考慮しておく必要もある。

従って,こてでは遺伝子の操作を行った生活種の排 水処理への適用に関してその安全性, 効果, 経済性等 あらゆる面からの検討を行い所要のガイドラインを作 成する。

（2）遺伝子組換え等による処理生物種の開発

排水処理に適した微生物, 有価物を産出する微生物 は自然条件下では適応性が低く大量の自然増殖は期待 できない，従っててれらの有用微生物の遺伝子を，大 腸菌, 酵母菌, 枯草菌などの菌株に組み込み, 有用種 の開発を行うとともに，乙れら有用種の保存法・大量 培養法の研究を行う。

また，突然变異株の利用についても検討を行う. 
（3）細胞融合による処理生物種の開発

上記(2)と同様, 細胞融合によって新しい有用種の開 発を行い, 保存法・大量培養法の研究を行う。

\section{4. 物理化学処理 よの組合せ技術の開発}

固定化酵素・微生物を用いたバイオリアクターでは 下水中の固形物除去に対しては大きな効果を期待する ことはできない. そこで既存の物理化学処理プロセス とバイオリアクターを組み合わせたプロセスの開発を 行い, 最適排水処理プロセス及び有価物回収システム

\section{製品ニュース}

$\langle$ 下水道污水桝用 $>$

\section{異常時採水器兼排水監視装置 MODEL YS 8500}

建設省都市局下水道部の調查研究に協力し, 各 地方自治体の要望に沿って, 開発された同装置は 污水桝で水質監視ができる，消費電力の節約がで きる、採水のためにポンプを使はないという省エ ネ化を徹底させている。主な特徵は, 真空ポンプ を使わずに, ベローズ形の採水ビン自身の復元力 により生ずるバキュームを利用して試料を吸引す る. $\mathrm{pH}$ 計のゼロとスパン合せはマイクロコンピュ ータにより行われるため, ワンタッチでキャリブ レーションを行うことができる。污水栘内のイン バードにフィットするよう擬似インバードが数種 用意されている。水質・水位の計測は正常異常を 問わず 1 分毎に行われる. 異常時には採水指令が でてサンプリングし，10分毎のデータが記録され る. 正常時では毎正時のデータのみが記録される. 標準価格はプリンター込みで 130 万円.

問い合せ：アクアコントロール株式会社 東京都千代田区九段北1-7-3(昭栄ビル) TEL 03(234)3541

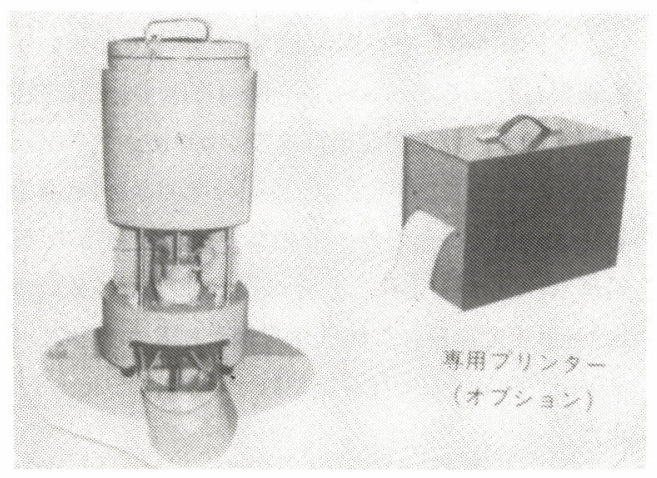
アクアコントロール(株)
の計画指針を作成する.

\section{5. 実際の排水処理システムへの新技術の適用に関す る研究}

バイオリアクターと物理化学処理との組み合わせプ ロセスのうち, 早急に効果の期待のできる改善的プロ セスのパイロットプラントを建設し, 都市下水及び各 戸排水処理の実用化実証試験を行う。さらに実験結果 を解析し, 各施設の設計指針・維持管理指針を作成す る.

\section{界面検知器チェックボーイ}

水や污泥などの界面を近赤外線によって検知し, 音で知らせる界面検知器「チェックボーイ」は, センサの検知素子間で発行・受光が行われ, 光が さえぎられた時に音を出すのが基本原理. 発光量 が一定であれば受光量は，検知素子間の気液界面 や液中濃度の差によって変化する。チェックボー イは, このわずかな変化量を精密に検出できるよ うにしたもので，設定つまみを12段階に切換える ことによって, 気液の界面検知から污泥界面など 液界面検知まで幅広く対応することができる、設 定レベルより, 受光量が少なくなると, ブザーが 鳴るので, その時のセンサーコードの長さから界 面の位置を知ることができる。浄化槽, 下水処理 場, 浄水場, 工場排水処理施設, ビル・工場の給 排水施設などの維持管理に使用できる. 主な特長 は, 小型軽量, 密閉構造のため雨天時での使用も 可能, 近赤外線を使用しているので, 液の色の影 響は殆どない, 暗所でも使用可能なアラーム方式 である等, 価格 98,000円.

問い合せ：株式会社西原環境衛生研究所 東京都港区芝浦三丁目 6 番18号 03(455)4821内 530

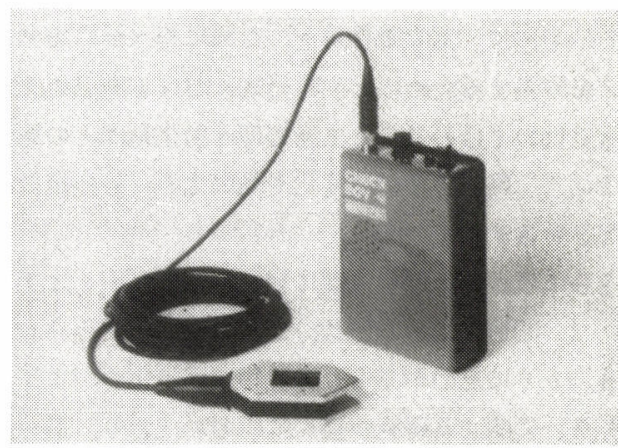

株西原環境衛生研究所 